\title{
NOTA DE APRESENTAÇÃO
}

Desta vez, GESTÃO E DESENVOLVIMENTO apresenta-se em número duplo (N. os $^{5}$ - 6), correspondente aos anos de 1996 e 1997. Entendemos que, no processo de fidelização dos leitores a uma revista científica, além do conteúdo e da pertinência dos temas focados, também a regularidade da publicação desempenha função relevante. Daí o nosso esforço, para que não se verifiquem atrasos significativos.

Numa altura em que este número já se encontrava em fase avançada de elaboração - mais precisamente em 10 de Maio de 1997 - , faleceu, inesperadamente, a Dra. Maria da Graça Ferreira, assistente do Instituto Universitário de Desenvolvimento e Promoção Social (IUDPS), que gozava de grande estima e consideração, entre aqueles que com ela trabalhavam ou conviviam. Revelando sempre um grande empenho e competência em tudo o que fazia, possuidora de uma excepcional força de vontade e de um notável dinamismo, havia concluído há pouco, no Instituto Superior de Ciências do Trabalho e da Empresa (ISCTE), o seu Curso de Mestrado em Políticas de Gestão e Recursos Humanos. Sem perder tempo, como era seu timbre, iniciava, de imediato, os trabalhos preparatórios com vista ao Doutoramento. A sua promissora carreira académica foi, assim, abruptamente interrompida.

Ficou a saudade e o exemplo de dedicação e entusiasmo para todos aqueles que tiveram o grato ensejo de a conhecer ou de, com ela, trabalhar. Como aluna, inicialmente, como colega, depois, ou ainda como colaboradora de GESTÃO $E$ DESENVOLVIMENTO, é-me grato sublinhar a competência, o entusiamo e mesmo a alegria com que desempenhava as tarefas que lhe competiam.

A homenagem do IUDPS e da GESTÃO E DESENVOLVIMENTO manifesta-se numa secção de abertura, sob o título «Graça Ferreira - In Memoriam», com diversos testemunhos. Seguem-se os vários artigos, distribuídos pelas seguintes subsecções: I-Competitividade, Educação e Economia; II - Cultura Organizacional; III - História, Cultura e Turismo. Como habitualmente, incluem-se ainda, neste número: Vida e Actividades do Instituto (IUDPS), Escaparate, Revistas Recebidas por permuta com "Gestão e Desenvolvimento" e Livros recebidos a título de oferta. 